\title{
INCLUSIVE EDUCATION IN BANGKA BELITUNG PROVINCE OF INDONESIA: CHALLENGES AND OPPORTUNITIES
}

\author{
Wahyu Kurniawan \\ IAIN Syaikh Abdurrahman Siddik Bangka Belitung \\ wahyulapter@gmail.com \\ Demisa Nurhasanah \\ IAIN Syaikh Abdurrahman Siddik Bangka Belitung \\ demisanurhasanah@gmail.com
}

\begin{abstract}
Abstrak: In Indonesia, the practice of providing education for children with special needs since 1901 has been held by social institutions and religious groups. The radical change began in 1990 when discussing a strong paradigm of inclusive education with humanist content. The core of this paradigm is the existence of services provided towards diversity in uniformity. This paper is intended to explore the paradigm of inclusive education and challenges and opportunities in the Bangka Belitung Islands Province. This paper contains library research and the personal experience while in the field to discuss the Children with Special Needs (ABK) and map the opportunities and challenges of inclusive education services in the Bangka Belitung Islands Province. The findings include: 1) Inclusive education spans a long history to the present, from segregative to inclusive patterns; 2) Educational Development includes multi-dimensional content that includes content modification, approaches debate, structure, and paradigms that support more the sense of humanity; 3) Challenges in Bangka Belitung include the problem of qualified schools that have not reached a balanced ratio with the number of needs; 4) Bangka Belitung has potential that requires good government support, community support, and the socio-cultural conditions of Bangka Belitung that are needed with multiculturalism issue.
\end{abstract}

Kata Kunci: History of Inclusive Education, opportunities and challenges of implementing inclusive schools, Children with Special Needs (ABK)

Abstrak: Di Indonesia, Praktik penyelenggaraan pendidikan bagi anak berkebutuhan khusus bermula sejak tahun 1901 telah diselenggarakan oleh lembaga-lembaga sosial masyarakat maupun kelompok-kelompok keagamaan. Perubahan secara radikal mulai berawal pada tahun 1990 dimana munculnya paradigma pendidikan inklusi yang kuat dengan muatan-muatan humanis. Adapun core dalam paradigma ini adalah adanya pemberian layanan terhadap keberagaman di tengah keseragaman. Tulisan ini bertujuan untuk mengupas paradigma pendidikan inklusi beserta tantangan dan peluangnya di Provinsi Kepulauan Bangka Belitung. Tulisan ini mengoperasikan penelusuran kepustakaan

Submission Date Review Date Publish Date
: April 07, 2020

; April 16, 2020 : June 01, 2020 
dan pengalaman penulis selama di lapangan untuk mengeksplorasi tentang ruang lingkup Anak Berkebutuhan Khusus (ABK) dan memetakan peluang dan tantangan layanan pendidikan inklusi di Provinsi Kepulauan Bangka Belitung. Temuan tulisan ini antara lain: 1) Pendidikan inklusi merentang dalam sejarah yang panjang hingga saat ini, dari pola segregatif hingga inklusif; 2) Perkembangan Pendidikan inklusi mencakup multidimensi yang mencakup modifikasi konten, pendekatan, struktur, dan paradigma yang semakin menghargai humanitas; 3) Tantangan di Bangka Belitung mencakup isu ketersediaan sekolah yang mumpuni belum mencapai rasio yang seimbang dengan jumlah kebutuhan; 4) Bangka Belitung mempunyai potensi yang menyangkut isu dukungan pemerintah yang baik, dukungan masyarakat, dan kondisi sosial budaya Bangka Belitung yang terbiasa dengan multikulturalisme.

Kata Kunci: Sejarah Pendidikan Inklusi, peluang dan tantangan penerapan sekolah inklusi, Anak Berkebutuhan Khusus (ABK) 


\section{Pendahuluan}

Penulisan singkat ini tentu saja diawali dari perjalanan karir penulis setelah menyelesaikan studi magister profesi psikologi di Yogyakarta sejak tahun 2015, kemudian bekerja di Pusat Layanan Autis Provinsi Bangka Belitung dimana penulis diminta menjadi asessor di pusat layanan autis. Ketertarikan pada anak berkebutuhan khusus lainnya pula diawali dengan dibukakannya layanan asesmen anak dengan segala macam indikasi dengan beragam hambatan. Walaupun di pusat layanan autis secara spesifik hanya menerima anak dengan indikasi autis namun pelayanan asesmen tidak saja terhenti pada layanan autis saja melainkan anak-anak lainnya.

Perjalanan ini terus berlanjut dengan adanya undangan undangan dari beberapa SLB di Prov. Kep. Bangka Belitung untuk mempelajari dan mendalami segala macam hambatan dan gangguan Anak Berkebutuhan Khusus atau penyandang disabilitas, menghadiri beberapa pelatihan, workshop, seminar tentang anak berkebutuhan khusus baik di Bangka Belitung, Bandung, Blitar, Denpasar. Dari sini pulalah awal pertemuan dengan beberapa ahli seperti bertemu dengan salah satu psikolog Senior ibu Endang salah satu pengajar di fakultas psikologi di Surabaya, bertemu dengan pakar terapis ABK bapak Ito Budi Waskita serta perjumpaan dengan beberapa praktisi PLB yang bekerja sebagai dosen tetap di UPI Bandung bapak Dr. Endang Rohyadi M.Pd yang fokus pada materi Inklusi , Terapis Wicara di Provinsi Kepulauan Bangka Belitung, Fisioterapi di Bangka Belitung. Lambat laun menjadikan penulis semakin merasakan bahwa penting untuk dikaji lebih jauh mengenai ABK. Hal ini tidak lain dan tidak bukan dikarenakan anak anak berkebutuhan khusus semakin hari semakin meningkat dan mereka sering mendapatkan diskriminasi dalam realitas masyarakat setempat. Perjalanan terus berlanjut hingga saat ini dalam peningkatan kapasitas dan pendampingan Anak Berkebutuhan Khusus.

Penulisan artikel ini diracik pula berdasarkan pengalaman penulis sejak tahun 2016 ketika diminta memberikan pelayanan asesmen dan identifikasi anak dengan kecenderungan berkebutuhan khusus di sekolah-sekolah seputaran Pangkalpinang, dan terus berlanjut dikala penulis menjalani MoU dengan beberapa sekolah di Kabupaten Bangka Tengah, Bangka Barat, Bangka Selatan, Bangka Induk, serta perjumpaan dengan beberapa narasumber pusat yang fokus pada penerapan sekolah inklusi. Tentu saja tuisan ini hanya secerca catatan dalam perjalanan di lapangan. Tentu dalam penulisan ini bukan sebatas asumsi melainkan data lapangan yang dibuat dalam kesimpulan singkat dikarenakan tulisan ini akan dikembangkan bagi riset ke depan.

Anak merupakan dambaan bagi seluruh orangtua. Anak ialah generasi yang dipersiapkan untuk melanjutkan estapeta/eksistensi keluarga. Biasanya di awal awal proses pembuahan/ perkawinan tidak jarang orangtua pula menempatkan harapan yang setinggitingginya untuk anaknya kelak. Namun, tidak jarang pula terkadang anak dilahirkan tidak sesuai dengan harapan yang diinginkan atau anak dengan 
kondisi berkebutuhan khusus. Anak dengan Berkebutuhan Khusus ialah anak Anak yang mengalami gangguan fisik, mental, sosial, dan emosional (Mangunsong, 2014). Gangguan ini biasanya sudah terdeteksi pada masa kehamilan hingga usia dini tumbuh kembang.

Bersandingan penjelasan di atas, banyak defenisi yang di semata dalam menterjemahkan apa itu $A B K$, seperti defenisi yang dikemukakan oleh Garnida (2018), yang menjelaskan bahwa anak berkebutuhan khusus memiliki arti yang lebih luas dibandingkan dengan anak luar biasa. Anak berkebutuhan khusus ialah anak yang dalam sisi pendidikan memerlukan pelayanan yang spesifik, berbeda dengan anak pada umumnya. Anak berkebutuhan khusus ini mengalami hambatan dalam belajar dan perkembangan. Oleh sebab itu, anak berkebutuhan khusus memerlukan layanan pendidikan dan kebutuhan yang khusus.

Garnida (2008) menambahkan pula ABK sendiri terbagi dalam dua macam antara lain adalah ABK yang sifatnya permanen dimana $\mathrm{ABK}$ ini cenderung menetap, dari lahir, gangguan biologis sedangkan kedua ialah temporer yang sifatnya dipengaruhi bukan dari lahir, bisa dari lingkungan, kondisi peperangan, korban bullying dan sebagainya.

Blackhurst, et al. dalam Aziz (2018) menjelaskan ABK sendiri dapat diterjemahkan ke dalam beberapa penyebutan antara lain impairment yang ditandai dengan rusak, cacat atau sakit yang bermuara adanya gangguan biologis. Sedangkan yang berikutnya adalah handicap, cenderung tidak bisa mengakses lingkungan dan terakhir adalah disability, istilah ini dapat diterjemahkan tidak lengkapnya, hilang, kurangnya fungsi dari sensor. Menguatkan pendapat di atas, WHO pada tahun 2007 memaparkan hal yang sama antara impairment dan disability. Impairmet diidentikkan dengan defisit atau abnormalitas pada sturktur tubuh atau fungsi fisiologis yang mencakup fungsi mental. Sementara disability ialah melingkupi impairment namun adanya aspek negatif dalam interaksi antara individu dan faktor kontekstual yang melingkupi lingkungan dan faktor personal (Handayani \& Azura, 2018). Sedangkan handicapped ialah dimaknai dengan ketidakmampuan individu yang disebabkan dari impairment atau disability sehingga individu tidak dapat melakukan peran sosial yang sangat esensial.

Peristilahan di atas, terlebih di Indonesia baru disebutkan dalam undang-undang secara khusus pada tahun 1950 melalui UUD No. 4, kemudian disusul dengan Undang-Undang No. 12 tahun 1954 dengan istilah anak cacat atau dengan anak dengan ketunaan atau anak dengan kekurangan. Anak berkebutuhan khusus lainnya dikenal pula dengan istilah exceptional child yang mencakup anak yang mengalami kelainan, sehingga mereka membutuhkan pelayanan dan pendidikan secara khusus. Ahli lainnya juga menyebutkan definisi tentang anak berkebutuhan khusus ini adalah ABK adalah anak dengan karakter yang berbeda dengan lainnya dari sisi mental, sensori, komunikasi, perilaku sosial serta karakteristik fisik (Hallahan \& Kauffman, 2006).

Sementara itu, dalam Konvensi Hak-Hak Penyandang Disabilitas pada tahun 2006 yang diratifikasi melalui UU 
No. 19 tahun 2011, disabilitas dijelaskan sebagai hasil dari interaksi antar orangorang dengan keterbatasan kemampuan dan sikap dan lingkungan yang menghambat partisipasi penuh dan efektif mereka di dalam masyarakat berdasarkan kesetaraan dengan yang lainnya (The United National dalam Handayani \& Azura, 2018).

Secara umum ABK dapat dikategorisasikan dalam: a) Anak dengan masalah belajar dan perilaku yang melingkupi anak dengan tunagrahita, kesulitan belajar, autisme, ADHD, tunalaras; sedangkan b) anak dengan disabilitas Fisik dan sensori berupa tunarungu, tunawicara, tunanetra, tunadaksa; dan c) Ialah anak dengan kemampuan intelektual superior atau anak dengan bakat istimewa (Handayani \& Azura, 2018). Adapun penjelasannya dijelaskan di bawah ini (Kementerian pendidikan nasional, 2010):

Pertama, Tunarungu adalah suatu istilah umum yang menunjukkan kesulitan mendengar dari yang ringan sampai berat, digolongkan ke dalam tuli dan kurang dengar. Orang tuli adalah yang kehilangan kemampuan mendengar sehingga menghambat proses informasi bahasa melalui pendengaran, baik memakai ataupun tidak memakai alat bantu dengar dimana batas pendengaran yang dimilikinya cukup memungkinkan keberhasilan proses informasi bahasa melalui pendengaran. Sedangkan klasifikasi berdasarkan atas ambang batas kemampuan mendengar terdiri atas ringan (26-54 dB), sedang (55-69 dB), berat (70-89), dan sangat berat (90 dB k eatas).

Kedua, ketunadaksaan yaitu seseorang yang mengalami kesulitan mengoptimalkan fungsi anggota tubuh sebagai akibat dari luka, penyakit, pertumbuhan yang salah bentuk, dan akibatnya kemampuan untuk melakukan gerakan-gerakan tubuh tertentu mengalami penurunan. Sedangkan, secara definitif pengertian tunadaksa adalah ketidakmampuan anggota tubuh untuk melaksanakan fungsinya disebabkan oleh berkurangnya kemampuan anggota tubuh untuk melaksanakan fungsi secara normal sebagai akibat dari luka, penyakit, atau pertumbuhan yang tidak sempurna sehingga untuk kepentingan pembelajarannya perlu layanan secara khusus. Dengan demikian, dalam memberikan layanan disekolah memerlukan modifikasi dan adaptasi yang diklasifikasikan dalam tiga kategori umum, yaitu kerusakan saraf, kerusakan tulang, dan anak dengan gangguan kesehatan lainnya. Kerusakan saraf disebabkan karena pertumbuhan sel saraf yang kurang atau adanya luka pada sistem saraf pusat.

Ketiga, anak tunagrahita memiliki IQ di bawah rata-rata anak normal pada umumnya. Sehingga menyebabkan fungsi kecerdasan dan intelektual mereka terganggu yang menyebabkan permasalahan-permasalahan lainnya yang muncul pada masa perkembangannya. Oleh karena itu, dalam keterangannya terdapat beberapa hal yang perlu diperhatikan, seperti : 1). Fungsi intelektual umum secara signifikan berada dibawah rata-rata, maksudnya bahwa kekurangan itu harus benar-benar meyakinkan sehingga yang bersangkutan memerlukan layanan pendidikan khusus. Sebagai contoh, anak 
normal rata-rata mempunyai IQ (Intelligence Quotient) 100, sedangkan anak tunagrahita memiliki IQ paling tinggi 70; 2). Kekurangan dalam tingkah laku penyesuaian (perilaku adaptif), maksudnya bahwa yang bersangkutan tidak/kurang memliki kesanggupan untuk melakukan pekerjaan-pekerjaan yang sesuai dengan usianya. Ia hanya mampu melakukan pekerjaan seperti yang dapat dilakukan oleh anak yang usianya lebih muda darinya; 3). Ketunagrahitaan berlangsung pada periode perkembangan, maksudnya adalah ketunagrahitaan itu terjadi pada usia perkembangan yaitu sejak konsepsi hingga usia 18 tahun. Berdasarkan beberapa uraian di atas dapat disimpulkan bahwa tunagrahita mengacu pada fungsi intelekual umum yang berada di bawah rata-rata yang menyebabkan kesulitan dalam beradaptasi seperti kesulitan dalam melakukan kegiatankegiatan yang sesuai dengan usianya dan berlangsung sejak dalam kandungan hingga usia 18 tahun.

Keempat, Tunalaras adalah individu yang mengalami hambatan dalam mengendalikan emosi dan kontrol sosial. Definisi anak tunalaras atau emotionally handicapped atau behavioral disorder lebih terarah. Anak dengan hambatan emosional atau kelainan perilaku, apabila menunjukkan adanya satu atau lebih dari lima komponen berikut ini: tidak mampu belajar bukan disebabkan karena faktor intelektual, sensori atau kesehatan, tidak mampu untuk melakukan hubungan baik dengan teman-teman dan guru-guru, bertingkah laku atau berperasaan tidak pada tempatnya, secara umum mereka selalu dalam keadaan tidak gembira atau depresi, dan bertendensi ke arah simptom fisik seperti merasa sakit atau ketakutan yang berkaitan dengan orang atau permasalahan di sekolah. Para orangtua menerapkan disiplin rendah terhadap anak-anaknya tetapi selalu memberikan reaksi terhadap perilaku yang kurang baik, tidak sopan, suka menolak sepertinya dapat menjadi sebab seorang anak menjadi agresif, nakal atau jahat.

Kelima, Tunawicara. Anak dengan hendaya pendengaran dan bicara (tunarungu tunawicara), pada umumnya mereka mengalami hambatan pendengaran dan kesulitan melakukan komunikasi secara lisan dengan orang lain. Bila dibandingkan dengan anak cacat lainnya, penderita tunawicara cenderung tergolong yang paling ringan, karena secara umum mereka tidak kelihatan memiliki kelainan dan tampak seperti orang normal.

Keenam, Tunanetra. Anak yang mengalami hambatan pengelihatan atau tuna netra atau anak dengan hendaya penglihatan, perkembangannya berbeda dengan anak-anak berkebutuhan khusus lainnya, tidak hanya dari sisi pengelihatan tetapi juga dari hal-hal lain. Bagi peserta didik yang memiliki sedikit atau tidak melihat sama sekali, harus mempelajari lingkungan sekitarnya dengan menyentuh dan merasakannya. Perilaku untuk mengetahui objek dengan cara mendengarkan suara dari objek yang akan diraih adalah perilakunya dalam perkembangan motorik. Untuk dapat merasakan perbedaan setiap objek yang dipegangnya, anak dengan hambatan pengelihatan selalu menggunakan indera raba dengan jari-jarinya. Kegiatan ini merupakan perilakunya untuk menguasai dunia presepsi dengan menggunakan indera sensorik. 
Ketujuh, Kesulitan belajar. Anak dengan kesulitan belajar merupakan salah satu jenis anak berkebutuahan khusus yang ditandai dengan adanya kesulitan untuk mencapai standar kompetensi (prestasi) yang telah ditentukan dengan mengikuti pembelajaran konvensional. Learning disability merupakan salah satu istilah yang mewadahi berbagai jenis kesulitan yang dialami anak terutama yang berkaitan dengan masalah akademis, kesulitan bidang akademik di sekolah yang sangat spesifik yaitu kesulitan dalam satu jenis/bidang akademik seperti berhitung/matematika (diskalkulia), kesulitan membaca (disleksia), kesulitan menulis (disgraphia), kesulitan berbahasa (dysphasia), kesulitan tidak terampil (dispraksia\}.

Kedelapan, Autis ialah merupakan gangguan perpasif dimana diidentikan dengan kata autos/ automatic dimana berjalan sendirinya. Dalam makna lain autis ini dicirikan kesulitan dalam merespon dan mencirikan diri dengan emosi dan isyarat sosial, tidak mampu membedakan isyarat ekpresi yang jelas, kurang memiliki empati dan simpati yang kuat, ekpresi yang kaku, mudah meledakledak, perilaku yang kerap berulang, sulit diajak berkomunikasi, menyendiri, mengabaikan situasi disekelilingnya.

Kesembilan, Anak dengan kecerdasan diatas rata rata/Supernormal ialah anak dengan kecerdasan diangka kurang lebi 170-200 keatas, secara intelegensia pada dasarnya sangat baik, namun pada aspek kepribadian belum tentu terintegrasi dengan baik, semakin tinggi IQ semakin sulit untuk beradaptasi dan hal ini yang menyebabkan memerlukan pelayanan khusus Baker (Tirtonegoro, 1984). Hal lain pula ditemukan pengalaman pribadi yang tidak stabil, tidak dapat menyesuaikan diri, sangat emosional, tidak bisa diberikan kritikan, tidak bisa menjadi pemimpin diantara IQ lainnya.

Kesepuluh, Anak dengan lamban belajar/ slow learner ialah anak yang memiliki potensi intelegensia sedikit dibawah anak normal tetapi anak ini tidak termaksud dalam kategorisasi anak dengan tunagrahita biasanya memiliki IQ kisaran 80-70, dalam penjelasannya anak ini dicirikan dengan lemahnya pada aspek berpikir, lamban dalam memberikan respon dalam aktfitas kesehariannya namun kemampuannnya diatas dari anak dengan tunagrahita, dari sisi lain kemampuan berpikir abstraknya cenderung lebih rendah dari sisi fisik anak ini pada dasarnya tidak ada masalah apapun dan normal. Namun, pada saat di kelas cenderung lambat dalam menerima pelajaran, sering mengalami remedial, jarang memberikan respon kosa kata yang banyak, adapun ciri lainnya adalah anak ini biasanya memiliki nilai sekolah dibawah 6, lambat dalam mengerjakan pekerjaan yang diberikan di sekolah, daya tangkap pada mata pelajaran cenderung lambat, pernah tinggal kelas, waktu yang dibutuhkan anak lambat belajar ialah lebih lama dibandingkan dengan anak lainnya (Garnida, 2018).

Di Indonesia sendiri Anak ABK dengan populasi terbesar keempat di dunia, jumlah anak berkebutuhan khusus ternyata cukup banyak. Jika dilihat dari angka dalam tahun pada tahun 2003 anak berkebutuhan khusus diperkirakan sebanyak $0.7 \%$ penduduk Indonesia dari 
211.428.572 yang artinya terdapat 1.480.000 Jiwa diindikasikan ABK, sedangkan data 2009 anak ABK mengalami peningkatan sebanyak 2.126.998 (BPS dalam Aziz 2018). Mengenai data terbaru di Indonesia memang belum punya data yang akurat dan spesifik tentang berapa banyak jumlah anak berkebutuhan khusus. Berdasarkan data dari www.kemdikbud.go.id (diakses pada tanggal 11 Oktober 2018), data anak ABK di Indonesia mencapai 1,6 juta. Namun, secara umum PBB memperkirakan bahwa paling sedikit ada 10 persen anak usia sekolah yang memiliki kebutuhan khusus di dunia. Mengenai jenis ABK sendiripun cenderung beragam dari berbagai tingkatan dan kategorisasi baik yang ringan, sedang, berat dan sangat berat.

Adapun penyebab lahirnya anak dengan berkebutuhan khusus antara lain ialah, sejak sebelum kelahiran adapun penjelasannya ialah semenjak anak dalam kandungan yang biasanya tidak disadai oleh orangtua seperti gangguan genetik yang berdampak pada kromosom, transformasi, sisi lainnya seperti infeksi kehamilan yang disebabkan adanya parasit golongan protozoa dari hewan hewan tertentu seperti penularannya dari hewan anjing, burung, tikus. Sisi lainnya seperti usia ibu hamil dengan reskio, tinggi badan kurang $145 \mathrm{CM}$, berat badan dibawah standar. Setelah proses kelahiran seperti kekurangan oksigen, vacum, kehamilan terlalu lama, keracunan ketuban dan terakhir adalah setelah kelahiran seperti terkena virus TBC, kekurangan gizi, kecelakaan.

\section{Potret Perjalanan Pendidikan Terhadap Anak Berkebutuhan Khusus dari Segregatif hingga Inklusif}

Konsep pendidikan anak berkebutuhan khusus dapat ditelusuri dengan mengikuti perjalanan historis dari perkembangan pendidikan $\mathrm{ABK}$ itu sendiri. Beberapa perjalanan sejarah munculnya ide memberikan pelayanan kepada anak berkebutuhan khusus pada dzaman reinesans pada masa ini pendampingan terhadap $\mathrm{ABK}$ terkesan cukup unik. Pada perkembangan selanjutnya yaitu pada abad ke 16, beberapa usaha telah dilakukan untk membantu individu yang mengalami gangguan penglihatan, seperti oleh Spaniard Fransisco Lucal dari Saragosa yang membuat surat melalui pahatan dalam tulisan di sebuah kayu untuk membantu orang dalam gangguan penglihatan. Pada abad 16 ini pula ada suatu kemiripan metode yang hampir mirip dengan huruf braile yang pernah dikembangkan oleh Girolima Cardano dari Italia untuk memberikan pelayanan khusus pada orang individu yang memiliki masalah dalam penglihatan (Wagg dalam Dapa 2019).

Berlanjut pada abad 17 dan 18, pendampingan pada $A B K$ mulai semakin jelas dimana terdapat perubahan tingkah laku sosial dan moral masyarakat menyangkut pelayanan terhadap ABK. ada perubahan pandangan dalam memberikan pelayanan dan perhatian sebagaimana anak normal lainnya. beberapa filosof yang memberikan perhatiannya antara lain ialah John Locke dan Jean Jacques Rousseau yang memberikan sumbangan pemikirannya. Pada era ini mulailah muncul persepsi yang baik bagi pendidikan khusus yang 
disponsori oleh Saxe-Gotha, sekolah umum Amerika, kemudian sekolah amal perta untuk perkembangan pendidikan kristen di Inggris, dan beberapa sekolah khusus untuk anak tunarungu dan tunanetra.

Pada abad berikutnya adalah pertengahan abad 18, didirikannya sekolah de I'Eee's untuk tunarungu, sekolah Valentin Hauys untuk tunanetra di Paris tempat Louis Braille belajar dan kemudian menemukan tulisan yang menggunakan 6 (enam) titik untuk membaca dan menulis tunanetra yang dikenal saat ini adalah Huruf Braille. Sekolah pertama untuk tunarunggu didirikan di Old Kent Road London, di samping kemajuan lain dalam bidang pendidikan bagi anak dengan gangguan sensoris di beberapa negara Eropa.

$\begin{array}{ccr}\text { Setahap } & \text { demi } & \text { setahap dunia } \\ \text { pendidikan } & \text { khusus } & \text { mengalami }\end{array}$ perkembangan yang sanga pesat dengan munculnya kasus kasus tertentu seperti kelemahan fungsi kognitif, ditemuakannya anak kecil usia 11-12 tahun senang mengelilingi tepian desa yang bernama aeyron dibagian prancis dan inilah awalmula ditemukan kasus anak muda mengalami Autis yang bernama viktor yang diperiksa oleh Philippe Pinel (Dapa, 2019).

Sekitar tahun 1877 ada tokoh perempuan yang peduli pada ABK yaitu Dr. Deteressa Maria Montessori, pada dzaman itu masih saja ditemukan bahwa lumpuh, idiot, adalah masalah medis. Setelah mempelajari cerita dari kasus Viktor yang diajarkan oleh Itard dan seguin montesori menarik kesimpulan bahwa masalah keterbelakangan mental lebih merupakan masalah pedagogis daripada masalah pengobatan atau medis. Yang di sinilah mulai adanya organisasi yang dibuat oleh Montessori disini selain ia mendampingi siswa dengan ABK namun memberikan pelatihan pada guru guru yang memiliki kesenangan dalam pendampingan ABK. Mulai adanya alat bantu dalam pengajaran, alat alat didaktif dan perjalanan sejarah ini hingga munculnya tokoh psikologi seperti Alfred dan Binet yang mulai menyusun skala usia untuk mengetes intelegensia, sebagai catatan mereka berdua menyusun skala bukan pada anak normal melainkan pada anak berkebutuhan khusus adapun maksudnya adalah pengkatagorisasian kelas-kelas khusus pada sekolah reguler (Dapa, 2019).

Di Indonesia, praktik penyelenggaraan pendidikan bagi anak berkebutuhan khusus bermula sejak tahun 1901 telah diselenggarakan oleh lembagalembaga sosial masyarakat maupun kelompok-kelompok keagamaan. Pemerintah baru mulai mengambil peran secara aktif dalam pendampingan secara nyata ialah di sekitaran tahun 1980an dimana membentuk sekolah dasa luar biasa, dimana anak anak berkebutuhan khusus didik secara bersama dalam satuan sekolah namun mereka masih terpisah dengan anak anak lainnya atau yang dikenal dengan sistem segeregatif. Filosofi yang melandasinya adalah bahwa mereka yang berkebutuhan khusus diberikan pelayanan secara terpisah dan sistem sekolah semacam ini masih dianggap diskriminasi (Budiyanto, 2017).

Pada pertengahan tahun 1980 Yayasan Helen Keller Internasional (HKI) mensponsori berdirinya sekolah terpadu (mainstreaming) terutama bagi anak 
tunanetra, bekerja sama dengan pemerintah. Adapun fiosofi yang mendasarinya adalah mendekatkan anak cacat pada dunia nyata, yaitu masyarakat secara luas. Sistem sekolah ini mendapat dukungan kuat dari pemerintah, namun masih kurang memperhatikan aspek budaya setempat karena berorienta si pada ide pencetus dan sponsornya. Dalam perjalananya pula program ini tidak berkembang sebagaimana yang diharapkan atau dengan kata lain kurang populer (Budiyanto, 2017)

Perubahan secara radikal mulai berawal pada tahun 1990 dimana munculnya paradigma pendidikan inklusi yang kuat dengan muatan-muatan humanis. Adapun core dalam paradigma ini adalah adanya pemberian layanan ditegah keseragaman. Adapun kuncinya adalah sistem pendidikan yang mampu menampung seluas mungkin masyarakat yang beragam . implikasi ini berdampak pada perubahan yang radikal baik dalam tataran konseptual maupun dalam operasional. Seperti dengan sebutan anak cacat digeser menjadi anak berkebutuhan khusus (Budiyanto, 2017).

Garnida (2018) menjelaskan sejarah panjang sekoalah inklusi ini awal mulanya ialah diprakarsai dan diawali oleh negara negara Scandinavia (Denmark, Norwegia, Swedia), sedangkan di Amerika Serikat dprakarsai oleh presiden Kennedy, mengirkan pakar-pakar pendidikan khusus kenegara Scandinavia untuk mempelajari konsep mainstreaming dan Least Restrictive enviroment yang ternyata sangat bisa diterapkan di negara Amerika serikat. Selanjutnya di negara Inggris dalam Ed.Act 1991 mulai dikenalkan dengan konsep inkulsi.
Pencanangan sekolah inklusi ini sendiri ini sebagaimana dituangkan dalam Bhineka Tunggal ika, dimana mengandung makna walaupun berbeda beda namun tetap satu jua dimana tidak ada perbedaan antar satu dan lainnya yang masuk dalam sila kedua dan sila kelima, dari sisi landasan lainnya sebagaimana yang dicantumkan dalam landasan sosial, dan hal lain tercantum dalam perundang undangan UU No 20 Tahun 2003 sistem pendidikan nasional, UU no 8 tahun 2016, Penyandang disabilitas , PP 17 tahun 201, penyelengaraan dan pengelolaan pendidikan, permendiknas no 70 tahun 2009 tentang pendidikan inklusi. Sejarah panjang pendidikan inklusi ini pula beriringan dengan perjalanan sejarah kehidupan manusia dan adab, sikap dan pandangan masyarakat terhadap penyandang disabilitas telah berubah secara signifikan, dari mulai memandangnya sebagai warga negara yang tidak berguna; warga negara yang perlu mendapat santunan; warga negara yang perlu dididik; hingga sampai pada masa di mana penyandang disabilitas dipandang memiliki hak yang sama dengan warga yang lain (Hallahan \& Kauffman, 1997). Penyandang disabilitas mendapat layanan pendidikan turut dipengaruhi oleh sikap dan cara pandang masyarakat terhadap penyandang disabilitas. Dengan kata lain, bagaimanakah sistem, proses, praktik, dan pendidikan, khususnya pendidikan bagi penyandang disabilitas tergantung pada filosofi yang mendasarinya. Secara internasional, layanan pendidikan bagi penyandang disabilitas telah berkembang dari yang tradisional hingga yang modern. Esensi dari pergeseran orientasi ini adalah perubahan cara pandang terhadap peserta 
didik sebagai objek material pendidikan yang berdampak pada pengembangan cara-cara intervensi yang lebih humanis (Direktorat PKLK, 2018). Dalam bahasa Inggris dikenal kata inclusive (inklusif), yaitu kata sifat yang berarti "termasuk", dan kata include yang merupakan kata kerja transitif dengan arti memasukkan.

Sedangkan kata bendanya adalah inclusion. Kata include berbeda dengan kata integrate dan segregarte sebagai kata kerja transitif yang berarti menggabungkan dan memisahkan. Integration merupakan kata benda yang berarti penggabungan dan segregation sebagai kata benda yang berarti pemisahan. Inklusi digunakan untuk menggambarkan suatu kelompok yang anggotanya dalam keadaan beragam atau bervariasi. Integrasi menggambarkan suatu kelompok di mana anggotanya beragam, tetapi setiap ragam berkumpul dalam kelompok tersendiri dalam kelompok tersebut. Sedangkan segregatif menggambarkan suatu kelompok yang anggotanya sejenis di mana anggota yang tidak sejenis dipisahkan dari kelompok tersebut (Direktorat PKLK, 2018).

Layanan pendidikan terhadap penyandang disabilitas mengalami perubahan yang cukup mendasar dari layanan pendidikan yang segregatif, integratif, dan inklusif. Diawali pendidikan segregatif merupakan layanan pendidikan bagi penyandang disabilitas yang diberikan secara terpisah antara penyandang disabilitas dan anak pada umumnya. Atau dengan kata lain, para penyandang disabilitas mendapatkan layanan pendidikan bersama-sama dengan penyandang disabilitas yang sejenis di tempat yang khusus dan terpisah dari anak-anak pada umumnya. Dalam sistem ini kita mengenal sekolah-sekolah khusus yang di Indonesia biasa disebut dengan Sekolah Luar Biasa (SLB). Pendidikan integratif (terpadu) merupakan layanan pendidikan di mana penyandang disabilitas bersekolah bersama-sama dengan anak pada umumnya di sekolah umum (reguler). Meskipun demikian, layanan ini Masih menyertakan persyaratan tertentu bagi penyandang disabilitas untuk dapat bersekolah di sekolah umum, misalnya harus memiliki kecerdasan normal. Sedangkan layanan pendidikan inklusif merupakan layanan pendidikan yang mengakomodasi semua keragaman peserta didik tanpa pengecualian. Dengan demikian, siapapun penyandang disabilitas dapat bersekolah di sekolah umum yang dikehendaki. Sehingga terdapat beberapa unsur dehumanisasi terhadap pendidikan di Indonesia khususnya pada anak berkebutuhan khusus (Direktorat PKLK, 2018).

Oleh karena itu, para praktisi pendidikan khusus menyelenggarakan konferensi pendidikan kebutuhan khusus (Special Needs Education) di Salamanca, Spanyol tahun 1994 yang menghasilkan Pernyataan Salamanca (Salamanca Statement). Pernyataan Salamanca pada intinya menyatakan agar anak berkebutuhan khusus (children with special needs) mendapat layanan pendidikan yang lebih baik dan berkualitas. Dalam konferensi ini istilah inclusive education (pendidikan inklusif) secara formal mulai diperkenalkan. Pendidikan inklusif tidak sama dengan konsep pendidikan integratif/terpadu. Pendidikan inklusif punya makna jauh 
lebih luas dari pada integrasi. Pendidikan inklusif tidak sekedar memindahkan atau menempatkan penyandang cacat di sekolah reguler. Dalam pendidikan inklusif anak harus diterima di sekolah tanpa syarat dan program sekolah harus menyesuaikan kebutuhan anak. Sedangkan dalam pendidikan integratif anak baru dapat diterima di sekolah jika anak dapat menyesuaikan proram yang ada di sekolah. Inklusi dipandang sebagai proses yang diarahkan dan merespon adanya kebutuhan peserta didik yang beragam dengan cara meningkatkan partisipasi dalam belajar, kegiatan budaya dan komunitas, dan mengurangi eksklusi dalam pendidikan (Direktorat PKLK, 2018).

Inklusi mencakup perubahan dan modifikasi isi, pendekatan, struktur, dan strategi dengan misi utamanya mengakomodasi semua anak berusia sekolah yang menjadi tanggung jawab sistem pendidikan reguler untuk mendidik mereka (UNESCO, 1994). Pendidikan inklusif diarahkan untuk mengakomodasi kebutuhan belajar yang sangat luas dalam setting pendidikan formal maupun informal dan tidak sekedar mengintegrasikan anak-anak yang termajinalkan dalam pendidikan mainstream. Pendidikan inklusif merupakan pendekatan untuk mengubah sistem pendidikan agar dapat mengakomodasi peserta didik yang sangat beragam. Tujuannya agar guru maupun peserta didik merasa nyaman dengan adanya perbedaan dan memandangnya sebagai tantangan dan pengayaan dalam lingkungan belajar, dan bukan menganggapnya sebagai masalah (UNESCO dalam panduan Direktorat PKLK, 2018).
Sejarah penyediaan akses pendidikan bagi difabel diteguhkan melalui beberapa kesepakatankesepakatan organisasi non-pemerintah dan badan dunia. Kesepakatan tersebut antara lain (Pratiwi, 2009):

Pertama, Deklarasi universal hak asasi manusia pada 1948 menegaskan bahwa setiap orang mempunyai hak atas pendidikan. Kedua, Konvensi Perserikatan Bangsa-Bangsa tentang hak anak pada 1989 mewadahi pasal tentang pendidikan yang antidiskriminasi, pendidikan berdasar kepentingan terbaik kelangsungan hidup anak, dan menghargai pendapat anak.

Ketiga, Deklarasi dunia tentang pendidikan untuk semua di Jomtien pada 1990 pasal 3 ayat 4 menyatakan bahwa sebuah komitmen aktif harus dibuat untuk menghilangkan kesenjangan pendidikan. Pasal 2 ayat 5 menyebutkan langkah-langkah yang perlu diambil untuk memberikan akses ke pendidikan yang sama pada tiap kategori penyandang cacat ditempuh sebagai bagian integral dari sistem pendidikan.

Keempat, Peraturan standar tentang persamaan kesempatan bagi para penyandang cacat pada 1993 mulai menyebutkan keharusan yang disediakan negara untuk konsep pendidikan bagi penyandang cacat yakni memiliki kebijakan yang jelas, kurikulum fleksibel, materi berkualitas dan memberi bantuan berkelanjutan. Masyarakat juga harus ikut berpartisipasi sebagai basis program. Pada akhir peraturan ini menyebutkan sekolah luar biasa tidak dikesampingkan jika pendidikan umum tidak memadai untuk tunarungu.

Sedangkan berikutnya kelima adalah pernyataan Salamanca 1999 dan 
Kerangka Aksi tentang pendidikan berkebutuhan khusus. Pada pernyataan Salamanca mulai diakui istilah sistem pendidikan inklusi dengan sepenuhnya menyesuaikan dengan kebutuhan anak penyandang cacat.

Keenam, Kerangka Aksi Forum Pendidikan Dunia di Dakar, Senegal pada 2000. Dalam kerangka Dakar, terdapat fokus yang lebih kuat untuk mengembangkan rencana aksi nasional yang kokoh dilengkapi strategi regional untuk memonitor dan evaluasi. Pemerintah dan lembaga lainnya juga berjanji menciptakan lingkungan pendidikan yang nyaman dan inklusi.

Ketujuh, Tujuan pembangunan milenium yang berfokus pada penurunan angka kemiskinan dan pembangunan pada 2000 yang telah didukung oleh Bank Dunia dan 149 kepala negara menyepakati salah satu tujuan utama yakni mencapai pendidikan dasar universal. 8. Flagship Pendidikan Untuk Semua tentang pendidikan dan kecacatan pada 2001 yang diluncurkan oleh United Nations Educational, Scientific, and Cultural Organization (UNESCO) dan kelompok kerja internasional untuk penyandang cacat dan pembangunan bertujuan menempatkan isu kecacatan dengan tepat pada agenda pembangunan dan memajukan pendidikan inklusi sebagai perwujudan pendidikan untuk semua. Tujuh Peraturan mengikat dan kesepakatan-kesepakatan badan dunia yang ada.

Di Indonesia, sejak tahun 1990 para kalangan profesional pendidikan luar biasa mulai ramai membicarakan tentang pendidikan inklusif dalam bentuk seminar-seminar, diskusi panel dan sejenisnya. Beberapa diantaranya dihasilkannya Deklarasi Malioboro pada tanggal 17 Maret 2001, di Bandung pada tahun 2002 dengan menggelar rapat dengan DPRD setempat adapun tuntutannya adalah penghapusan sistem sekolah yang eksklusif menjadi Inklusif. Selanjutnya Balitbang Depdiknas telah mengadakan kajian penerapan model sekolah inklusi di Gunung Kidul Yogyakarta dengan menerapkan sistem inklusi. Hasil ujicobanya ini selanjutnya digunakan sebagai model pengembangan pendidikan inklusi di Indonesia (Workshop PGPLB Dikti dalam Budiyanto, 2017).

Tindakan nyata selanjutnya dilakukan oleh direktorat PLB yang mengagendakan pendidikan inklusif telah masuk dalam agenda tahunannya dalam bentuk penyiapan dan pengkajian. Adapun fase dalam implementasi pendidikan inklusi dapat disimpulkan dalam beberapa tahap: 1). Ujicoba; 2). Sosialisasi; 3). Penguatan institusi; 4). Regulasi; 5). Pembinaan dan pengembangan (Kementrian Pendidikan nasional, 2010).

Pada tahun 2012 mulailah melakukan gerakan nasional pendidikan inklusi. Bentuk nyata program ini adalah dibentuknya POKJA pendidikan inklusi pada tiap provinsi yang menerima Bamper yang menyelenggarakan pendidikan inklusi. Dampak dari program ini sangat luas dan menggembirakan pada saat ini lebih dari 12 Provinsi dan 113 Kabupaten/kota inklusi yang telah mendeklarasikan diri sebagai Provinsi. Kota, Kabupaten dengan pencanangan inklusi. Adapun alur pelayanan pendidikan terhadap anak 
berkebutuhan khusus dapat dilihat dari bagan dibawah ini (Kementrian Pendidikan nasional, 2010)

Seiring perjalanannya waktu pendidikan inklusi mulai didengar dan berjalan dibelahan dunia dan khususnya Indonesia adapun tujuan dari dibentuknya sekolah inklusi antara lain: a). Memberikan kesempatan seluasluasnya kepada anak (berkebutuhan khusus) mendapatkan pendidikan yang layak sesuai dengan kebutuhannya; b). Membantu mempercepat program wajib belajar pendidikan dasa; c). Membantu meningkatkan mutu pendidikan dasar, menegah dengan menekan angka tinggal kelas dan putus sekolah; d). Menciptakan pendidikan dengan menghargai keseragaman tidak diskriminasi serta ramah terhadap pembelajaran; e). Mematuhi atuan UUD 1945, khususnya pasal 32 ayat 1 , UU 20 tahun 2003 tentang SPN.
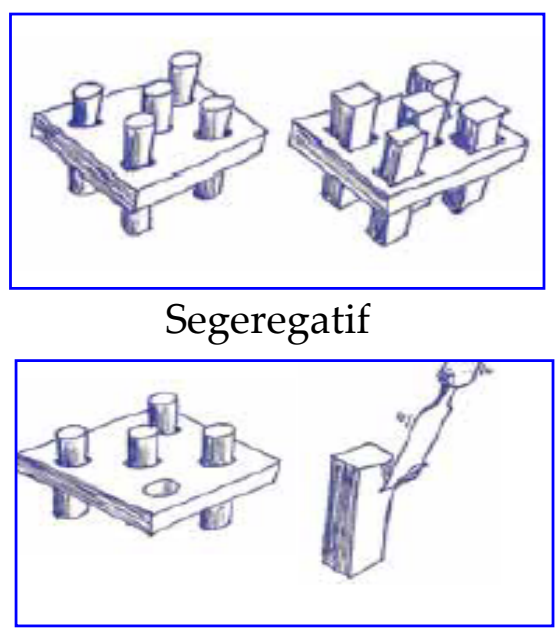

Interegatif

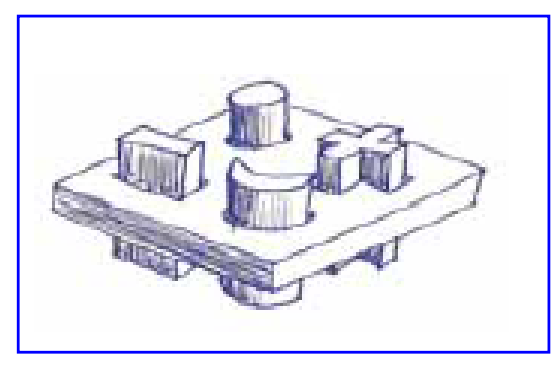

Inklusi
Perdebatan penyelenggaran pendidikan inklusi ini mendapatkan respon yang cenderung beragam, walaupun dengan adanya pemberlakuan perundang-undangan, adanya konvensi dunia, ada perjanjian dan sejarah masa lalu dengan adanya education for all namun pendidikan inklusi memuculkan pro dan kontra. Pada ahli yang cenderung pro pemberlakuan sekolah inklusi menyatakan bahwa antara lain: a). Tidak adanya bukti empirik bahwa dengan adanya SLB merupakan salah satu sistem terbaik dalam pendidikan berkebutuhan khusus; b). Biaya yang ditangguhkan di sekolah SLB cenderung lebih mahal; c). Banyak anak berkebutuhan khusus yang tinggal di daerah daerah terpencil sehingga tidak dapat mengakses SLB sehingga aksesbilitasnya terbatas; d). SLB cenderung memisahkan (yang tinggal diasrama) dari realitas masyarakat; e). Banyak anak berkebutuhan khusus di sekolah reguler tidak ditangani dengan baik; f). Implikasi dari SLB cenderung terlabelisasi dengan adanya anak cacat yang menimbulkan stigma sepanjang hayat, orang tua tentu tidak mau di SLB; g). Dengan adanya sekolah inklusi bisa menghargai segala perbedaan.

Pada ahli yang kontra menyatakan pula: a). hasil penelitian masih mencari formulasi yang tepat dalam menangani anak berkebutuhan khusus; b). perundang-undangan telah memfasilitasi ABK; c). Ada semacam ketakutan anak tidak mau menyekolahkan peserta didik di sekolag reguler yang dikenal memberlakukan sekolah inklusi (populer); d). Banyak sekolah reguler belum siap menyelenggarakan sekolah inklusi dikarenakan menyangkut keterbatasan sumber daya manusia; e). 
SLB lebih dianggap unggul (Garnida, 2018).

Menyelenggarakan pendidikan tanpa diskriminasi tentu saja bukan hal mudah maka diperlukan langkah-langkah dalam menjalankan sekolah inklusi, perlu diperhatikan pemahaman masyarakat terhadap sistem inklusi sehingga tidak ada kesenjangan pada masyarakat dan adanya ketakutan bahwa dengan dicampurnya dengan ABK tidak akan menjadi masalah pada anak normal lainnya, implikasi pada masyarakat, bagi masyarakat yang kontra tentu saja memunculkan anggapan yang berbeda, sisi lainnya perlu diperhatikan pula ialah penyelenggaraan baik keahlian, kelembagaan, pola kebudayaan. sisi lain perlu diperhatikan pula ialah mengenai kurikulum dan pendanaan (Garnida, 2018).

\section{Peluang dan Tantangan Pelaksanaan Pendidikan Inklusi di Provinsi Bangka Belitung}

Layanan pendidikan khusus, Khususnya SLBN di provinsi Bangka Belitung Saat ini hanya memiliki 7 (tujuh) SLBN yang terdaftar dikabupaten kota dan memiliki 2 Sekolah luar biasa yang swasta antara lain ialah YPN belinyu dan YPAC kota pangkalpinang dan pemerintah provinsi memiliki 3 (tiga) layanan keterapian antara lain di RSJ khusus tumbuh kembang anak di bawah Dinas Kesehatan Provinsi Kepulauan Bangka Belitung, di Pusat layanan Autis Provinsi Bangka Belitung dibawah Dinas Pendidikan dan Panti Rehabilitasi Sosial yang memberikan pelayanan keterapian wicara pada anak dengan gangguan wicara/hambatan wicara di Dinas Sosial.
Namun, jika dilihat dari daya tampung sekolah berdasarkan hasil dari temuan dilapangan maka data anak dengan ABK tidak sebanding dengan ketersediaan sekolah yang dimiliki saat ini sehingga memaksakan anak ABK tersebut tidak bisa dilayanan sebagaimana mestinya. Namun semenjak dicanangkannya inklusi sejak tahun 2015 muara pendidikan anak berkebutuhan khusus di Provinsi Bangka Belitung mulai memberikan warna baru dalam tautan positif pada anak berkebutuhan khusus.

Berdasarkan uraian di atas,
pendidikan inklusif
mengakomodasi semua kebutuhan anak dengan tidak mempersoalkan keadaan fisik, kecerdasan, sosial, emosional atau kondisi-kondisi lain. Di samping itu, dalam pendidikan inklusif harus ada elemen penting, yaitu: melibatkan semua pelajar, lokasi belajar yang sama, dan pelayanan yang disesuaikan dengan kebutuhan peserta didik, lantas pada akhirnya, apakah provinsi Bangka Belitung sudah benar benar siap dengan pelaksanaan sistem sekolah inklusi?

Jika dilihat dari jumlah angka anak berkebutuhan khusus sebagaimana yang telah digambarkan di atas, maka tentu saja pemberlakuan sistem pendidikan inklusi adalah salah satu solusi yang harus dijalankan mengingat akan dikemanakan anak anak berkebutuhan khusus untuk itu sejak 2015 sendiri melalui kebijakan Gubernur kala itu dan inisiasi dari kepala Dinas Pendidikan Provinsi Kepulauan Bangka Belitung menginginkan adanya pendidikan inklusi. Berdasarkan dari hasil temuan penulis dilapangan dalam beberapa kali pelaksanaan asesment anak dengan kecenderungan $A B K$ melalui 
assesment yang beragam yang bekerjasama dengan beberapa kabupaten kota yang dilaksanakan di Kabupaten Bangka Induk, Bangka Selatan, Bangka Tengah, Bangka Barat, kota Pangkalpinang lonjakan angka anak dengan kebutuhan khusus cenderung meningkat pada kasus anak dengan kecenderungan Tunagrahita, Slow Learner/Low Average dan data ini diperoleh dari hasil pengukuran alat ukur WISC, WAIS, S-FRIT, sedangkan angka yang lain ialah anak memiliki kecenderungan Tuarungu, CP, Autism, ADHD, dan tunalaras dan sesuai dengan kasus yang dialami anak, adapun data lengkap akan disampaikan pada penelitan yang sedang dilaksanakan oleh penulis bersama dengan tim.

Berbagai upaya yang telah dilakukan oleh Dinas Pendidikan Provinsi Kepulauan Bangka Belitung dalam memberikan edukasi kepada sekolah sekolah penyelenggara inklusi antara lain berdasarkan hasil penelusuran dari media online setidaknya pemerintah telah menyelenggarakan pelatihan antara lain telah dilaksanakan pada tahun 2015 dengan judul Bangka, Barometer pendidikan inklusi (www.radarbangka.co.id, edisi 5 April 2020), lainnya juga sebagaimana yang dilangsir dari situs www.pangkalpinang.go.id dengan judul berita pendidikan inklusi untuk anak berkebutuhan khusus, hal lainnya pula jika dilihat pada pemberitaan terbaru pada tanggal 3 Maret 2020 dengan judul pelatihan pengembangan pendidikan inklusi untuk anak berkebutuhan khusus tentu banyak program yang beragam pada pelatihan, baik dari program pusat maupun daerah.
Tentu saja dalam artikel ini penulis mencoba membersamai temuan-temuan dilapangan dikarenakan sejak tahun 2016 penulis cenderung terlibat dalam penjaringan siswa dengan kecenderungan ABK.

Berdasarkan dari hasil wawancara kepada seluruh kepala sekolah khususnya SD ditemukan beberapa kendala dalam pelaksanaan pendidikan inklusi antara lain adalah guru guru menemukan kesulitan cara untuk melakukan identifikasi dalam penentuan anak berkebutuhan khusus dikarenakan semua guru guru berlatar belaka umum sehingga memiliki kesulitan dalam menentukan varian eror dan varian strategis anak berkebutuhan khusus, program pelatihan tidak berjalan secara runut sehingga pola pembelajaran yang didapat oleh sekolah cenderung lompat dan tidak terarah. Dari data lainnya juga petugas atau penanggung jawab pendidikan inklusi cenderung berubah dan tidak tentukan secara permanet sehingga penangung jawab tidak bisa maksimal dalam pemberian pendampingan pada anak berkebutuhan khusus dikarenakan jika melihat dari beberapa referensi Garnida, Budiyanto, modul pelatihan inklusi cenderung harus ditentukan penaggungjawab yang cenderung mampu mengimplementasikannya.

Selain pada temuan di atas pula, tantangan selanjutnya adalah dukungan masyarakat dengan diberlakukannya sekolah inklusi cenderung mendapat pandangan yang beragam, antara lain orangtua takut menyekolahkan anak di sekolah yang sudah menyelengggarakan inklusi dikarenakan takut anak ABK akan mengganggu teman yang lain dan ketakutannya adalah ada beberapa 
orangtua menganggap bahwa $\mathrm{ABK}$ hanya boleh disekolahkan di SLB atau YPAC saja. maka jika ditelisik lebih lanjut formulasi yang perlu disentuh ialah kehadiran masyarakat dalam memberikan penilaian sekolah inklusi. Garnida (2018) menjelaskan hambatan budaya menjadi penentu ditengah ketidakmampuan masyarakat menerima dan memahami informasi terkait hadirnya anak ABK di sekolah reguler. Satu sisi lain pula jika anaknya ABK justru orangtua enggan secara budaya memasukkan anakknya kesekolah Khusus. Temuan lainnya juga adalah belum adanya alur pendaftaran yang jelas bagaimana sebenarnya awal mula anak ABK yang boleh tergabung pada sistem inklusi. Maka jika merujuk pada hasil pelatihan yang dikemukakan oleh Dr. Endang Rohyadi, perlu dan memasifkan pengetahuan pada orangtua dan guru terkait proses indentifikasi/assesment dari sisi perkembangan anak dan identifkasi dan asesment pada aspek pendidikan, dan semestinya sejak dini orangtua telah memahami hal tersebut dan begitupula pada para guru.

Sedangkan temuan lainnya adalah sekolah memerlukan semacam simulasi yang jelas bagaimana pengelolaan sekolah inklusi, dikarenakan hingga sampai saat ini guru guru merasakan kesulitan melaksanakannya pada tingkatan yang nyata sehingga guru tidak mengetahui secara pasti apa peran GPK, peran shadows teacher, guru kelas. Dari sisi Pasca pendidikan, biasanya juga orangtua dengan berkebutuhan khusus akan merasakan kebingungan mau kemana anak akan di sekolahkan dan bagaimana penjaminan hak hidup pasca di sekolahkan sehingga orangtua berharap ada semacam regulasi anak siap sekolah lanjut atau anak siap kerja yang diatur dalam Peraturan daerah

Terlepas dari belum lamanya pemberlakuan pendidikan Inklusi, penulis menganggap berapa potensi yang semestinya menjadi modal utama dalam pelaksanaan inklusi sehingga mampu menuju inklusifitas sosial. Inklusifitas adalah adalah dimana lingkungan secara umum mampu memberikan wadah pada anak berkebutuhan khusus baik dari sisi pendidikan, hingga pada hak hak dasar pada anak berkebutuhan khusus dimasyarakat. Tidak ada diskriminasi dari cara belajar, cara mendapatkan dan mengembangkan minat, arah vokasional anak pasca sekolah sehingga bisa lebih mandiri. Ragam peluang yang semestinya bisa menjadikan pendidikan Inklusi di Provinsi Kepulauan Bangka Belitung antara lain adalah pertama Bangka Belitung sudah terbiasa dengan adanya perbedaan itu sudah berlangsung lama, hingga saat ini pula di Provinsi Kepulauan Bangka Belitung belum ditemukan adanya konflik multikultural yang terjadi di Provinsi Kepulauan Bangka Belitung, sedangkan lainnya tipologi masyarakat yang masih menjunjung tinggi urun rembuk, musyawarah dalam masyarakat sehingga tepaselera, tenggangrasa dan saling memberikan dukungan masih tetap terjalin harmonis.

Hal lain pula belum pernah ditemukan kasus yang terjadi mengenai adanya masalah dalam pendampingan anak ABK di SLB, Inklusi yang telah ada, kini pula di Provinsi Kepulauan Bangka Belitung dari sisi peluangnya di setiap 
Kabupaten kota telah ada sekolah sumber yaitu SLBN dan Swasta di tiap tempat sehingga jika guru guru memiliki hambatan dapat mendapatkan informasi yang tepat. Dari sisi perundang undangan pula, Bangka Belitung telah memiliki Pergub terkait pendidikan inklusi sebagaimana dilansir dari http://jdih.babelprov.go.id tentang perubahan atas Peraturan Daerah Provinsi Kepulauan Bangka Belitung Nomor 4 Tahun 2016 tentang pengelolaan dan penyelenggaraan pendidikan pada Pasal 1 Poin 25.

Pada bidang ahli profesional, di Bangka Belitung sendiri memiliki banyak praktisi baik dari Guru PLB, Psikolog, sarjana Psikologi, Terapis dan adanya komunitas komunitas peduli anak ABK seperti Pondok lentera yaitu komunitas pada terapis dan praktisi ABK. Dari beberapa tahun belakangan pula Pemerintah daerah terus menambah kuota untuk formasi CPNS dalam tiap tahunnya baik yang berlatar belakangan menjadi terapis dan guru di SLB. Dari sisi Himpunan profesional pula di Bangka Belitung semakin hari semakin bermunculan misalkan saja dengan ada HIMPSI Babel dimana seluruh anggotanya adalah para Psikolog, Sarjana Psikologi dan akademisi psikologi, ada pula yang lain IFI, yaitu kumpulan pada ahli Fisioterapi, IDI ikatan dokter Indonesia, IKATWI dimana ada ikatan terapis Wicara Indonesia, IGPHI dengan ikatan Guru Pendidikan Khusus Indonesia, PERTUNI atau persatuan tunanetra Indonesia, GERKAFIN gerakan peduli dengan ketulian, YPD, Ikatan Bimbingan Konseling dan beragam oganisasi pendukung untuk kemajuan anak dengan berkebutuhan khusus.
Pada tahun-tahun belakangan diselenggarakan pula beragam pelatihan yang dilaksanakan oleh pusat dan daerah yang rutin dilakukan, perihal lainnya juga di Provinsi Kepulauan Bangka Belitung telah memiliki prodi yang berkaitan dengan dukungan pada anak berkebutuhan khusus seperti di IAIN SAS yang dibukakan prodi Psikologi Islam dimana mahasiswa akan dikenalkan bagaimana cara penanganan ABK, bagaimana cara melakukan assesment, sedangkan di UBB sendiri ada jurusan Sosiologi dengan mata kuliah Sosiologi anak berkebutuhan khusus, dan pada perguruan tinggi lainnya seperti di keperawatan dengan ada mata kuliah keperawatan anak sehingga anak bisa ditangani secara medis sejak dini, dari sisi lainnya juga berkat kebijakan Gubernur Provinsi Kepulauan Bangka Belitung pencanangan sekolah inklusi yang cenderung meningkat sehingga Inklusivitas Sosial bisa segera terwujud, Menilik lebih pada pandangan Garnida (2018, perlu diperhatikan pemahaman masyarakat terhadap sistem inklusi sehingga tidak ada kesenjangan pada masyarakat dan adanya ketakutan bahwa dengan dicampurnya dengan ABK tidak akan menjadi masalah pada anak normal lainnya, implikasi pada masyarakat, bagi masyarakat yang kontra tentu saja memunculkan anggapan yang berbeda, sisi lainnya perlu diperhatikan pula ialah penyelenggaraan baik keahlian, kelembagaan, pola kebudayaan. sisi lain perlu diperhatikan pula ialah mengenai kurikulum dan pendanaan. ${ }^{* * *}$ 


\section{Daftar Pustaka}

Mangunsong, F. (2014). Psikologi dan pendidikan anak berkebutuhan khusus (Jilid 1). Jakarta: LPSP3 UI

Mangunsong, F. (2014). Psikologi dan pendidikan anak berkebutuhan khusus (Jilid 2). Jakarta: LPSP3 UI

Tirtonegoro, \& Sutrarinah (2001). Anak supernormal dan program pendidikannya. Jakarta: Bumi aksara

Budiyanto (2017). Pengantar pendidikan inklusif. Jakarta: Kencana

Modul Pelatihan Pendidikan Inklusi. Kementerian pendidikan nasional (2009)

Friend, et al. (2015). Menuju Pendidikan inklusi panduan praktis untuk mengajar. Yogyakarta: Pustaka Pelajar

Suryani, et al. (2015). Asuhan keperawatan anak sehat dan berkebutuhan khusus. Yogyakarta: Pustaka Baru

Delphie, B. (2012). Pembelajaran anak tunagrahita. Bandung: Refika Aditama

Garnida, D. (2018). Pengantar pendidikan inklusi. Bandung: Refika Aditama

Dapa, Nixon A. (2019). Sistem Sosial anak berkebutuhan Khusus. Yogyakarta: Ombak.

Seri Sumbangan pemikiran psikologi untuk bangsa" Psikologi dan pendidikan dalam konteks kebangsaan (HIMPSI, 2018) 